\title{
Party Change and Policy Reform: Welfare Programs in the American States
}

\author{
Jill Clark and Thomas H. Little
}

This paper examines the effects of party control (Republican or Democrat) on state welfare policies after congressional passage of Temporary Assistance for Needy Families (TANF) in 1996. Interviews and surveys of legislative actors suggest that the adoption process in many states was highly partisan, but there was no relationship between party measures and welfare policy content for all states. Policy makers reported that welfare policy choices were influenced by the re-election context in a state. States that adopted more generous TANF policies had: competitive party systems, liberal ideologies, or previously high rankings on AFDC expenditures. Party positions redefined the welfare policy problem and set the parameters for welfare reform choices, but those choices were modified by contextual variables in some states. A few Republican governors accomplished comprehensive welfare policy reform.

\section{Party, Context, and Welfare Policy}

Since 1997 there has been a good deal of interest in describing state government responses to federal welfare reform, Temporary Aid for Needy Families (TANF). This reform represents the transformation of a longstanding entitlement program, Aid for Families with Dependent Children (AFDC), now TANF, to a block grant. While there is a federal mandate to reduce the number of welfare recipients, states have some leeway in specifying eligibility standards and conditions of aid. TANF legislation represents a unique opportunity to compare states, since they were required to formulate new welfare policies at the same time in 1997. Do party differences affect state TANF policymaking and policies? Do Republican policy makers choose more stringent TANF reforms and Democrats, more generous reforms?

Bibby and Holbrook $(1999,77-78)$ argue that there is good reason to focus on state parties, since they are changing and are now more distinct: "Liberals and moderates have become scarce at GOP state conventions, and the center of gravity at Democratic party gatherings has a pronounced liberal bent." Elite ideologies in state Democratic and Republican parties also show that all state Republican parties are conservative, and all but three state Democratic parties are liberal (Erickson, Wright, and McIver 1993). Policyoriented activists are presumed to be the driving force for these differences.

JILL CLARK is Associate Professor of Political Science at the University of Texas at Arlington; THOMAS H. LITTLE is Director of Curriculum Development and Research for the State Legislative Leaders Foundation.

The American Review of Politics, Vol. 23, Winter, 2002: 379-396

(C)2002 The American Review of Politics 
In spite of these party changes, only a few previous studies have found relationships (and fairly weak ones) between party and the differences in welfare policy (AFDC spending levels) (Liebermann and Shaw 2000; Rom, Peterson, and Shreve 1998). Brown (1995), on the other hand, finds that party control (Democrat or Republican) is related to AFDC expenditure levels in state party systems based on the New Deal coalition, where partisan conflict is organized along class-based lines. The differences between Democrats and Republicans on TANF reforms may also be more salient in this context. In short, does party make a difference in some circumstances, but not others?

Besides party affiliation, other factors also may affect the policy choices of Democrats and Republicans alike. A contextual approach (Hero 1998) suggests choosing factors that might influence policy makers' preferences for more or less stringent welfare reform. The relevant context for both Democrats and Republicans includes factors that may affect their reelection chances. The contextual variables included here are the strength of the governor's formal powers, the degree of inter-party competition (established competition or transforming), party control (unitary, dominant or divided), state ideology (conservative or liberal), and previous state rankings on AFDC spending levels. The expectation is that governors with strong institutional powers may be more visible and thus held accountable in the next election (Beyle 1999). Consequently, governors with strong formal powers will prefer moderate change and avoid the most stringent TANF policies. Another expectation is that policy makers in states with established two-party competition (Hamm and Moncrief 1999) will choose less stringent TANF policies, since the votes of "have-nots" may influence election outcomes (Barrilleaux 1997; Key 1949). If there is unitary party control of state policy making institutions, then the voters may hold the governing party accountable for policy choices. As a result, the expectation is that parties will choose more generous TANF policies where there is unitary party control (Gray and Eisenger 1997). Policymakers may also respond to citizens' ideological preferences in order to garner votes in the next election. The expectation is that policy makers in conservative states will choose more stringent policies than those in liberal states (Erickson, Wright, and McIver 1993).

Finally, a state's previous AFDC ranking may set parameters for policy makers in terms of where their state typically ranks in comparison to other states. State ranks in the 1990s were quite similar to those in the 1970s, and there is a clear pattern: neighboring states tend to have similar payment levels. Rom, Peterson, and Scheve (1998) find that this measure had an effect on year-to-year spending levels that was independent of political or economic variables. They conclude that previous AFDC expenditure levels 
reflect state policy makers' desires to keep welfare policies in line with their neighbors. Some policy makers may claim that generous TANF policies, such as high AFDC payments, will create a "welfare magnet"- that is, attract new welfare recipients to their state. The expectation then is that policy makers will keep TANF policies in line with neighboring states in order to avoid an electoral challenge. In short, a state's AFDC ranking and its TANF ranking will be similar. Are contextual variables more important influences on TANF policy than party?

This article examines the influence of party and contextual variables both in the state-level TANF policymaking process and in state policy choices. First, there is a description of the perspectives of state legislative actors involved in the 1997 TANF policymaking process. Data for the process study were gathered under the auspices of the State Legislative Leaders Foundation, and they are interviews of 117 participants in 15 states (1997) and a national survey of 300 state officials (2000). Respondents included legislative leaders, committee chairs, other legislators, welfare administrators, and welfare policy advocates. Note 1 reports the distribution of survey respondents, interviewees, and states where interviews were conducted. Next, there is an analysis of possible relationships between measures of party and contextual factors and the generosity or stringency of state welfare policy choices. Francis (1998) created the TANF stringency measure by combining thirteen possible welfare reform policy options where a state's choice on each one was characterized as either generous (scored +1$)$ or not generous (scored -1). State scores could range from plus thirteen to minus thirteen. Those states with the more negative scores are described here as more stringent or less generous and those with more positive scores as less stringent or more generous. The analysis involves simple cross-tabulations (Pearson's Chi Square) between each of the party and contextual variables and the measure of welfare policy stringency. The issue here is not the explanation of total variance in TANF policies, but whether party and contextual variables are relevant. Results from the cross-state analysis can be more easily compared to the policymaking process study. This approach also avoids problems of interpretation such as the obfuscation of interesting relationships when there are several independent variables but only 50 cases (Hero 1998).

\section{TANF Adoption: Devolution to the States}

The federal mandate to reduce caseloads opened the window of opportunity for state policy making. If the problem was defined at the federal level, then state TANF policy choices are not likely to show any relationship to conventional measures of state welfare dependency. There was an initial 
analysis here to determine the nature of relationships (Pearson's Chi Square) between state TANF stringency scores and indicators of differences in statelevel welfare "problems": the percent of the population on welfare, per capita income, the extent of minority diversity, and the size of pre TANF case load drops (compared to other states) There were no significant relationships between the extent of state welfare "problems" and policy stringency. Since state welfare "problems," are not related to TANF choices, some support is given to the argument that the welfare problem was defined nationally. This article will focus exclusively on the relevance of party and contextual variables to state TANF policy choices.

The next section of this article reviews the development of the welfare policy problem at the national level. There is a discussion the change of venue to the states and the factors that may impact their choice of solutions. Findings then follow on the state-level policy making process with an analysis of the possible relationships between party and contextual variables and policy stringency.

\section{Partisanship and Federal Welfare Policy}

Federal policy making in the area of welfare cash assistance has typically been partisan. New Deal Democrats initially led the effort to establish Aid for Dependent Children (ADC) as a means for providing increased funds for state Mother's Aid programs during the Great Depression. ADC was later changed to Aid for Families with Dependent Children (AFDC) during the Johnson Administration's War on Poverty. Larger cash benefits resulted since families, not just children, received support. Many Republicans opposed program expansion in the Johnson era, and conservative Republicans attacked AFDC by focusing on fraud and long-term welfare recipients. By the 1980s, President Reagan argued that welfare programs were the reason for persistent poverty, not the solution. Murray (1984) explicitly applied "the government is the problem" principle to welfare policy and found that AFDC encouraged poverty. His argument was that AFDC provided an incentive not to work; instead it promoted dependence and a "culture of poverty," rather than a culture of individual responsibility.

Following Murray's logic, conservative Republicans typically favored any policy that reduced eligibility or promoted work requirements for recipients. Conservative Republicans did not support expansion of the federal government role by providing more medical care, childcare and transportation assistance to working recipients (Dye 1998). However, some did support transitional services provided through block grants to the states (Bryner 1998). 
Most Democrats did not see government assistance as the reason for persistent poverty. In their view, poverty resulted from a lack of equal opportunity due to differences in the quality of schools, access to higher education, the decline of middle-class industrial jobs in central cities, and historical or contemporary discrimination against women and minorities. As a result, Democrats believed that the government should compensate the poor for unequal opportunities. Self-described "New Democrats" such as President Clinton redefined the government role from an entitlement based on need to the provision of assistance to become self-sufficient. However, they also accepted the Republican perspective that time limits and work requirements were reasonable incentives to encourage individual responsibility (Bryner 1998), and they agreed to block grants. Liberal Democrats, however, referred to these requirements as "regulating the poor"- that is, rules that limited recipients' eligibility for government assistance without helping them to help themselves (Skocpol 1995). They sometimes attacked sanctions for welfare recipients as both mean-spirited and excessively punitive (Dye 1998). They viewed the "culture of poverty" notion as both inaccurate (Saffell and Basehart 1997; Zimmerman and Gager 1997) and an attempt to "blame the victim."

In spite of differences within and between parties, a consensus for welfare reform developed between "New Democrats" and Republicans. The consensus was facilitated by Murray's (1984) policy goal to end welfare dependency and encourage individual responsibility. The new federal policy, TANF (1996), changed cash assistance from a federal entitlement program to state block grants. The federal accountability standard (reducing the number of recipients) was tied to future grants to states, and the amount of federal funds for the program was capped. The 1996 legislation set maximum time limits for welfare eligibility (five years) and a two-year limit for recipients without work. Medicaid coverage was available for recipients making the transition to work, and there were more federal dollars for childcare expenses. All except two House Republicans voted for the bill (The Personal Responsibility and Work Opportunity Reconciliation Act), but Democrats split 98 to 98 . There were 21 "no" votes in the Senate; all were cast by Democrats. In effect, the federal government had defined the poverty problem. Solutions were left to the states including eligibility and penalties for noncompliance with work regulations.

\section{A Change of Venue: Republican Advantages}

States could choose policy solutions that fit the Republican problem definition: limit eligibility and closely monitor the behavior of recipients as a means of reducing the rolls. Alternatively, they could adopt the Democratic 
policy image and provide assistance (such as transportation assistance) for recipients making the transition to self-sufficiency and set less stringent behavioral standards. Devolution was typically regarded as a victory for Republicans (Walker 1995), since competition among states for business development was thought to be an incentive for states to reduce governmental expenditures for welfare (Peterson 1995). Further, many states wanted to avoid becoming "welfare magnets" by offering welfare benefits at a level high enough to attract potential recipients from less generous states (Peterson and Rom 1990). Politicians used the "welfare magnets" idea, whether accurate or not, to gain leverage over welfare policy, i.e., to reduce benefits (Allard and Danziger 2000; Schram and Soss 1998).

The venue change to the states might also have advantaged the Republican strategy in another way because the relative power of participants was altered in comparison to the national level (Baumgartner and Jones 1993). Republican governors were innovators for welfare reform during the AFDC waiver period (Lieberman and Shaw 2000). Their reforms provided an impetus for changes in other states and for TANF legislation. Professional bureaucrats in state welfare agencies often provided the specifics of policy reform. Since the GOP enjoyed a considerable advantage (32 to 17) in 1997 in the number of state governorships, executive department bureaucrats were more likely to work for Republican governors than for Democrats. Gais $(2000,174)$ describes the pattern of Republican leadership in Midwestern states: "A striking feature has been the salient and often dominant role played by governors and top state executives and the contrasting political weakness of state legislatures." Weissert $(2000,8)$ suggests that Republican governors in Midwestern states not only set the agendas, but ". . . used their political resources to translate their vision into policy."

The possible "veto points" to welfare reform presented by welfare advocates (children's advocacy groups, urban interests, unions and minority groups) were probably limited in state capitols. Lieberman and Shaw (2000) argue that devolution allowed local elites to make policy, and these elites were typically uninterested in the needs of the poor. In a recent survey of state legislators, Shaw (2000) finds that lawmakers relied more heavily on social service agencies and the governor's office than on advocates for information on social policies. If this was generally the case, then Republicans may have faced less well-organized interest group opposition at the state level than at the federal level. Francis (1998), however, suggests that advocates found agencies amenable to their TANF ideas in Rhode Island, Vermont, New Hampshire, and Maine. Interestingly, Rhode Island and Vermont had the most generous TANF policies in the nation in 1997; Vermont ranked fourth most generous; New Hampshire ranked at the median (Francis 1998). Of these states, only Rhode Island had a Republican governor. 
These expectations regarding party differences and contextual variables will now be explored in interviews and surveys of the participants in the policy making process. The interviews focused on the specifics of welfare reform and the influence of party positions and re-election context on policy choices. The survey asked legislative leaders, welfare administrators and policy advocates in the fifty states to comment on the successes and failures of state TANF programs and to detail the policy components central to program successes.

\section{Policy Making from Perspectives of the Participants}

\section{Partisan Differences among Legislators}

Interview data from 1997 reveal that some states managed a bipartisan reform effort, but most divided along party lines over the differences in policy strategies. A Republican leader from a Northeastern state underscored the partisan divisions. "No, Democrats were not invited. It was a recognition of political realities, and I do not think there was any meaningful effort on their part to come to the table." Republicans generally preferred stricter regulations that would move people off the welfare rolls. Democrats typically supported transitional aids such as childcare and transportation assistance. Few Democrats supported the most stringent regulations for recipients. Leaders from one southern state also succinctly expressed the partisan differences. A Republican stated, "Those who do not want to work are on their own," while a Democratic leader said, "Most on the rolls are legitimate and needy."

Partisan differences in policy strategy also show up in state legislators' evaluations of the reasons for case load declines and parallel the party differences developed at the national level. Republicans and Democrats were asked what factors were very important in accounting for the caseload declines. The list of factors from which they could choose included a strong economy, time limits, a decrease in the amount of benefits, a family cap (no more aid for more children), job training programs, child care assistance, transportation assistance and transitional health care coverage. Legislators could indicate that more than one factor was very important. The percentages of Democrats and Republicans who rated each of the factors as very important are displayed in Table 1.

As expected, larger percentages of Republicans than of Democrats attributed declines in case loads to conditions of aid (time limits and a family cap). Larger percentages of Democrats than of Republicans credited assistance (child care, transportation, and health care) for the decline in cases. For Republicans (56\%), the most important policy factor was time limits; for 
Table 1. Attributed Sources of Shrinking Welfare Rolls (percentage of legislative leaders citing the factor as "very important"*)

\begin{tabular}{lccc}
\hline Statement & $\begin{array}{c}\text { Percent of } \\
\text { Republicans }\end{array}$ & $\begin{array}{c}\text { Percent of } \\
\text { Democrats }\end{array}$ & Difference \\
\hline Decreased Benefits & 17 & 7 & 10 \\
Time Limits & 56 & 31 & 25 \\
Family Cap & 29 & 8 & 22 \\
Job Training Programs & 34 & 38 & 4 \\
Child Care Assistance & 30 & 50 & 20 \\
Transportation Assistance & 14 & 24 & 10 \\
Health Care Coverage & 22 & 38 & 16 \\
Strong Economy & 64 & 83 & \\
N=211 & $(118)$ & $(93)$ & \\
*Leaders could cite multiple factors as "very important." & & \\
\hline
\end{tabular}

Democrats $(50 \%)$, childcare. Overall, the largest percentage differences between Republicans and Democrats were on the time limits, family cap, and childcare alternatives.

One Midwestern leader suggested a reason for support of time limits, "We have had work requirements for a long time, but there was no club. I personally think that time limits are the club. You have to have a reason for people to get a job." Another leader supported the emphasis on transitional support, "It shouldn't be work first. It should be families first, or maybe education first. We must make the move off welfare meaningful. We must make it last longer than a minimum wage job." About the same percentages of both party's leaders rated job training programs as a very important factor. More leaders of both parties cited a strong economy more than any other factor as very important, although more Democrats (83\%) saw the strong economy as a more important factor than Republicans (64\%).

Table 2 indicates that while large percentages ( $80 \%$ or more) of both Democrats and Republicans rated welfare reform as successful or very successful, Democrats were less likely to rate the programs as very successful. Over 46 percent of Republican leaders chose the very successful category, but only 14 percent of Democrats rated welfare reform as very successful. The differences may relate to the definition of success in the mind of the respondent. One leader, for example, suggested, "I think the rolls are going down because people can't deal with the system —or the system doesn't deal with them." 


\section{Welfare Administrators and Welfare Policy Advocates}

Interviews indicate that about half of the leaders saw governors as agenda setters for welfare reform, and all governors identified as agenda setters were Republicans. Leaders also viewed welfare administrators as the most important actors in the formulation process. In general, they indicated that advocates had very little influence on the content of the legislation. Some suggested that advocates were shut out of the process by legislators; others reported that advocates were shocked by the proposals and did not participate. In a few cases advocates recognized the inevitability of reform and attempted to influence the content of the legislation. One advocate stated, "The most meaningful thing we achieved was what I hope was an enduring change in the way some legislators look at the welfare issue. I hope one of the results is that it was a little educational about who it is that these proposals really affect."

Differences between the roles of advocates and administrators in the policy making process are reflected in their differing perceptions of the success of welfare reform (Table 2) and their views on whether state welfare reforms have successfully provided job training, job placement, educational supplements, transportation, quality child care, adult health care, child health care, and information about program benefits to recipients (Table 3).

Table 2 shows that 55 percent of administrators rated welfare reform as very successful. Overall, they saw reform as more successful than did advocates, Democrats, or Republicans. However advocates saw the reform as less successful than either administrators or legislators. In fact, no advocates viewed reform efforts as very successful, and 63 percent reported that reforms were not very successful or unsuccessful. Advocates' views were closer to those of Democrats in rating the success of the programs than to those of Republicans. The views of welfare administrators were closer to Republicans than to Democrats.

Table 2. Perceptions of the Success of Welfare Reform

\begin{tabular}{lccc}
\hline & $\begin{array}{c}\text { Percent } \\
\text { Very Successful }\end{array}$ & $\begin{array}{c}\text { Percent } \\
\text { Successful }\end{array}$ & $\begin{array}{c}\text { Porcent } \\
\text { Not Very Successful } \\
\text { or Unsuccessful }\end{array}$ \\
\hline Republican Legislators ( $\mathrm{n}=118)$ & 46 & 49 & 5 \\
Democratic Legislators $(\mathrm{n}=93)$ & 14 & 67 & 19 \\
Administrators (n=41) & 55 & 45 & 0 \\
Advocates (n=42) & 0 & 37 & 63 \\
Rows sum to 100\%. & & & \\
\hline
\end{tabular}


Table 3. Perceptions of Successful Provision of Elements of Welfare Reform (percentage agreeing that the state has successfully provided ...)

\begin{tabular}{lcc}
\hline & $\begin{array}{c}\text { Percent of } \\
\text { Administrators }\end{array}$ & $\begin{array}{c}\text { Percent of } \\
\text { Advocates }\end{array}$ \\
\hline Job Training & 92 & 31 \\
Job Placement & 97 & 42 \\
Educational Support & 61 & 18 \\
Transportation & 84 & 21 \\
Quality Child Care & 95 & 27 \\
Adult Health Care & 84 & 30 \\
Child Health Care & 100 & 76 \\
Information & 92 & 9 \\
N & 41 & 42 \\
\hline
\end{tabular}

The views of advocates and administrators were also quite polarized about the success of state provision of welfare services (Table 3 ). In general high percentages of administrators indicated that the state has provided transitional services for recipients, but dramatically smaller percentages of advocates agreed. For example, 84 percent of administrators saw successful provision of transportation services, but only 21 percent of advocates shared that view. About 95 percent of administrators believed that state had successfully provided quality childcare assistance, but only 27 percent of advocates agreed. Nearly all administrators (92\%) said the state had been successful in providing information to recipients, but only nine percent of advocates agreed. Nearly all administrators and advocates had extremely different views about the success of state efforts to provide transitional assistance to recipients.

\section{Contextual Variables: The Re-election Calculus}

The interviews and survey results confirm the expectations drawn from previous research on welfare policies. Legislators viewed the policy process as highly partisan, and the policy positions taken by Republicans and Democratic state legislators reflected those of the national parties. Many leaders also indicated that they saw the reform effort related to party campaigns, particularly the successful campaigns of Republican governors. One leader from a northeastern state said that the Republican governor "... believed that one of the reasons he won in 1994 was his stand on welfare cheats. That may or may not have been why he won, but he believed it and set the whole 
welfare reform in process." Republican leaders in eighteen states and Democrats in two states had adopted a state "Contract with America," modeled on then U.S. House Speaker Gingrich's 1994 strategy. The state contracts had a similar pledge-i.e., significant changes in the welfare system that would promote individual responsibility. As a result many leaders expressed the view that the welfare reform issue would be salient in the minds of voters in the next election. They felt that votes on welfare reform were cast under the scrutiny of the media and the public.

Leaders saw their task in welfare reform as putting together the coalitions to pass legislation. This leadership role was not easy, given the partisan differences over policy strategies and the attention of the governor and the public on this issue. Most were concerned about formulating policies that would satisfy the public in the next election, and policy advocates were often ignored. Partisan policy positions mattered, but certain electoral contexts may have dampened the effects of partisan differences and thus led to more moderate policy choices. The next issue, then, is the relevance of party and contextual variables to the stringency of policy choices for the population of states.

\section{Policy Stringency, Party, and Contextual Characteristics}

Policy stringency is measured by a composite scale of thirteen TANF policy options created by Francis (1998). The items include drug testing, denial of aid to drug felons or to legal non citizens, life time welfare eligibility limits, Medicaid and child care assistance beyond the federal minimum, family caps, diversion assistance, subsidized employment, community service requirements, individual development accounts, work requirements earlier than the federal mandate, and different treatment of recipients from other states. A state received a plus one for the more generous option and a minus one for the more stringent option. Actual state scores ranged from 11 (the most generous score) to -5 (the most stringent score), and the median was 3.0. Two categories are used in the following analysis: high stringency and low stringency. There were more states in the high stringency category due to several states with the same score. Other variables used in the analysis are also dichotomized, and relationships are reported in simple percentage tables. The test statistic for significance is Pearson's chi square.

The first question is the nature of the relationship between the governor's party identification and the stringency of state policies. The expectation is that Republican governors will choose more stringent policies. The results in Table 4 show the expected relationships. Fifty percent of states with Republican governors have less stringent policies, compared to 65 percent with Democratic governors. Fifty percent of states with Republican 
Table 4. Relationships between State Policy Stringency and Governor's Party

\begin{tabular}{lcc}
\hline & $\begin{array}{c}\text { Governor's Party Affiliation }\left(\mathrm{N}=49^{*}\right) \\
\text { Percent } \\
\text { Democrat }\end{array}$ & $\begin{array}{c}\text { Percent } \\
\text { Republican }\end{array}$ \\
\cline { 2 - 3 } Policy Stringency & 65 & 50 \\
Less Stringent & 35 & 50 \\
\cline { 2 - 3 } & In New Deal Party Systems (N = 18**) \\
& Percent & Percent \\
Democrat & Republican \\
\cline { 2 - 3 } & 83 & 42 \\
Less Stringent & 17 & 58 \\
More Stringent & & \\
Not significant at the .05 level. & & \\
* Maine is excluded because the governor was an independent. & \\
**New Deal party systems as classified by Brown (1995). & \\
\hline
\end{tabular}

governors have high stringency policies; only 35 percent with Democratic governors do. Although the relationship between governor's party and policy stringency is in the direction predicted, it is not statistically significant.

Brown (1995) suggests that party control will matter only in New Deal states - those where the cleavage between the two parties is along classbased lines. Results show that in New Deal states (Brown 1995), Democrats had a higher percentage of less stringent scores $(83 \%)$ in comparison to Democrats in the population of states $(65 \%)$; fewer such states had more stringent scores (17\%) than in the population (35\%). More Republicans in New Deal states had more stringent policies than in the population of Republican states. Fewer Republicans had less stringent policies than in the population of Republican states. In other words, more Democratic governors chose less stringent policies in New Deal states, and the differences between Democrats and Republicans are greater in New Deal states than in the population of states. The relationship between governor's party and policy stringency is not statistically significant.

Governors with strong institutional powers (Gray and Eisenger 1997) may choose less stringent policies. Strong governors have four-year terms, executive budget powers, cabinet governments and extensive item veto powers. Weak governors have only some or none of these powers. Strong formal powers may enhance the governor's leadership role in the welfare reform policymaking process, and these governors may be more visible to 
the public. As a result, strong governors may be held accountable for welfare reform. Results in Table 5 confirm the direction of the relationship between the strength of gubernatorial powers and the stringency of welfare policies. Governors with strong institutional powers were more likely to be in states with generous welfare policies, while those with weak powers had more stringent welfare policy choices. This relationship is not statistically significant. (Relationships are regarded as significant at the .05 level, but Table 5 includes results of variables significant at both the .1 and .05 levels.)

A party system factor sometimes associated with differences in state welfare policies is the degree of inter-party competition (Hamm and Moncrief 1999). Following Key's (1949) argument, the expectation is that "havenots" will fare better where their votes are relevant to election outcomes. As Table 5 shows, policy makers in states that have established party competition chose more generous welfare policies. Policy makers in states with

\section{Table 5. Relationships between State Policy Stringency and Contextual Variables}

\begin{tabular}{|c|c|c|}
\hline \multirow[t]{2}{*}{ Welfare Policy } & \multicolumn{2}{|c|}{ Governor's Powers* } \\
\hline & Strong & Weak \\
\hline \multirow{4}{*}{$\begin{array}{l}\text { Less Stringent } \\
\text { More Stringent }\end{array}$} & $66 \%$ & $40 \%$ \\
\hline & $34 \%$ & $60 \%$ \\
\hline & \multicolumn{2}{|c|}{ Inter-Party Competition** } \\
\hline & Competitive & Transforming \\
\hline \multirow{4}{*}{$\begin{array}{l}\text { Less Stringent } \\
\text { More Stringent }\end{array}$} & $69 \%$ & $38 \%$ \\
\hline & $31 \%$ & $63 \%$ \\
\hline & \multicolumn{2}{|c|}{ State Ideology** } \\
\hline & Liberal & Conservative \\
\hline Less Stringent & $67 \%$ & $39 \%$ \\
\hline \multirow[t]{3}{*}{ More Stringent } & $33 \%$ & $61 \%$ \\
\hline & \multicolumn{2}{|c|}{ Previous AFDC Spending Rank** } \\
\hline & More Generous & Less Generous \\
\hline Less Stringent & $71 \%$ & $40 \%$ \\
\hline More Stringent & $29 \%$ & $60 \%$ \\
\hline \multicolumn{3}{|c|}{$\begin{array}{l}* \mathrm{p} \geq .10 ; * * \mathrm{p} \geq .05 \text {. } \\
\text { Note: The Governor's Powers index is from Gray and Eisenger (1997); the Inter-Party Competition } \\
\text { measure from Hamm and Moncreif (1999); the State Ideology measure from (Wright, Erickson, and } \\
\text { McIver) 1994; and the Previous AFDC Spending Rank from Rom (1999). }\end{array}$} \\
\hline
\end{tabular}


transforming party systems chose more stringent policies. The relationship between degree of party competition and policy stringency is significant. This relationship confirms the finding of Soss et al. (2001) for three post TANF policy specifics.

The expectation is that single party control of state institutions (1997) will be associated with less stringent policies, since a single party in the legislative and the executive branches may be held accountable in elections. Here, "single party control" states are those with the governor and both houses of the legislature from the state party; "dominant party" states are those with the governor and one legislative house from the same party; "divided party control" states are those with the governor from one party and both legislative houses controlled by the other party. Nearly two-thirds of policy makers in states with single party control chose more generous welfare policies, but those in states with dominant or divided party control split almost equally between generous and stringent policies. The relationship is not statistically significant. Furthermore, there are no significant relationships between the two parties either within or between one-party, dominant, or divided party control states. In short, party control of the policymaking institutions, like party control of the governorship, is not related to the choices of more of less generous TANF policies.

The expectation is that states where citizens with conservative beliefs (Wright, Erickson, and McIver 1994) dominate will choose more stringent policies than liberal states. Governors and legislatures who formulate stringent welfare policies in a liberal state might face public disapproval and possibly negative electoral consequences. Results show that policy makers in states with liberal ideologies chose more generous policies, and those in conservative states chose more stringent policies. These relationships are statistically significant.

There is also a significant relationship between state rank on AFDC spending (Rom 1999) levels and the generosity or stringency of post TANF policies. As expected, states that ranked above average in AFDC spending chose more generous TANF policies. Rom, Peterson, and Scheve, Jr. (1998) argue that this measure reflects state policy makers' desires to keep their welfare spending levels in line with their neighbors. Otherwise, policy makers may be held accountable by voters for creating a "welfare magnet."

A closer examination of the data (AFDC and TANF) shows that six states did make the change from a history of generous AFDC spending to stringent TANF polices. All of these states had Republican governors in 1997: Wisconsin (Tommy Thompson), Minnesota (Arne Carlson), Illinois (Jim Edgar), Massachusetts (William Weld), Connecticut (John G. Rowland), and California (Pete Wilson). Several of these governors were at one time suggested as possible Presidential candidates for the Republican Party. 
There were also four states with a history of low AFDC spending levels that chose generous TANF policies. These states were Kentucky, Missouri, South Carolina, and Texas. Two of the states had Democratic governors, Kentucky and Missouri, but Texas and South Carolina had Republican governors. Interestingly, the Texas governor, George W. Bush, successfully ran for President as a "compassionate conservative."

Overall, party control of the governor's office or the legislature was unrelated to welfare policy choices. Three contextual variables may be useful in distinguishing the circumstances when state policy makers are likely to choose more or less generous welfare policies.

\section{Discussion: Party Control and Political Context}

The case study interviews and survey results suggest that the adoption of TANF policies in some states was highly partisan. For all states, however, party control (Republican or Democrat) of governorships and legislatures was not associated with either more or less stringent TANF policies. It is not unusual for case studies to identify variables that may matter in some contexts, but not in others. Furthermore, without the interviews and surveys, the conclusion might have been that party positions were not key factors in TANF policy choices. The relevant contexts may be policymakers' perceptions of the effect of welfare policy choices on re-election, and both the case study and cross-sectional analysis provide some support for this argument. States with two-party competitive systems, liberal citizens, or a history of generous AFDC spending chose more generous TANF policies. Any one of these variables (party competition, citizen ideology, and AFDC rankings) may provide a context for policy makers to weigh the trade offs between adhering to well-defined party positions and possible negative consequences for their re-elections. Many policymakers may be pragmatic and compromise by accepting some of the more generous TANF options. Republican governors and/or legislators in a state may favor most of the more stringent TANF options, but given a liberal electorate, high levels of party competition, or a history of high AFDC spending, these policy makers may accept a less stringent policy. Even if there are more ideologically distinct state parties, some politicians will moderate their positions to the context of the state.

A few Republican governors facing at least one of these contextual factors were not pragmatic and accomplished more comprehensive welfare reforms. These governors may have seen an opportunity both to promote change in welfare programs and gain national visibility for their accomplishments as policy entrepreneurs. Perhaps these governors, following core conservative beliefs on welfare reform, were developing records that would 
make them possible contenders for a Republican Party Presidential nomination. Furthermore, the success of these entrepreneurial governors may encourage their peers in neighboring states or Republican governors in other parts of the country. The intergovernmental perspective on welfare reform shows that a few entrepreneurial Republican governors initiated reforms during the AFDC waiver period. Congressional Republicans later capitalized on these successes in the enactment of TANF. Congress is currently considering renewal of TANF, and Republicans now control both houses of congress and the Presidency. Perhaps the records of governors who accomplished comprehensive TANF reform will affect the renewal legislation.

Over time Republicans may see more of their welfare reform ideas adopted due to changing conditions in states. Some Republican governors may view the initial TANF policy as a starting point, and incremental adjustments toward greater or less stringency may occur later. While the Republican Party advantage has decreased over time (Republicans now control 26 governorships and Democrats control 24), the effects of contextual variables may diminish over time. Adjustments to welfare policies will likely garner much less public and media attention than did the comprehensive changes in 1997. In fact, some of these changes may be delegated to welfare agencies or to local governments, typically more closed arenas than the legislature. There is already evidence that by 1999 more states had adopted more of the stringent policy options included in the Francis' index (Rowe 2000).

\section{NOTES}

${ }^{1}$ Dr. Thomas H. Little, coauthor of this article, is Director of Research at The State Legislative Leadership Foundation and was responsible for data collection. The SLLF research was funded by grants from the Annie E. Casey and David and Lucille Packard Foundations. Additional information about the interviews and survey can be obtained by contacting Dr. Little. Interviews were conducted in 1997 in the following states: California, Colorado, Connecticut, Florida, Illinois, Maryland, Michigan, Mississippi, New Jersey, New York, Ohio, Oklahoma, Pennsylvania, Texas, and Wisconsin. Sixty-six percent of interviewees were from the legislative branch; 21 percent from the executive branch; and 13 percent were policy advocates. The party affiliations of legislative and executive branch interviewees are as follows: 56 percent Democrats and 44 percent Republicans.

In 2000, the survey was administered to legislative leaders and committee chairs in all 50 states; to administrators in 38 states; and to advocates in 26 states. Forty-nine percent of respondents were legislative leaders; 23 percent committee chairs; 14 percent administrators; and 14 percent policy advocates. Legislative and partisan identifications is as follows: 56 percent Republicans and 44 percent Democrats. 


\section{REFERENCES}

Allard, Scott, and Sheldon Danzinger. 2000. Welfare Magnets: Myth or Reality? Journal of Politics 62:350-369.

Barrilleaux, Charles J. 1997. A Test of Electoral Competition and Party Strength in a Model of State Policy Making. American Journal of Political Science 41:15621566.

Baumgartner, Frank R., and Bryan D. Jones. 1993. Agendas and Instability in American Politics. Chicago: University of Chicago Press.

Beyle, Thad. 1999. The Governors. In Politics in the American States, 7th ed., eds. Virginia Gray, Russell L. Hanson, and Herbert Jacob. Washington, DC: CQ Press.

Bibby, John F., and Thomas M. Holbrook. 1999. Parties and Elections. In Politics in the American States, 7th ed., eds. Virginia Gray, Russell L. Hanson, and Herbert Jacob. Washington, DC: CQ Press.

Brown, Robert D. 1995. Party Cleavages and Welfare Effort in the American States. American Political Science Review 89:23-33.

Bryner, Gary. 1998. The Great American Welfare Debate: Politics and Public Morality. New York: W.W. Norton.

Dye, Thomas R. 1998. Understanding Public Policy, 9th ed. Upper Saddle River, NJ: Prentice-Hall.

Erickson, Robert S., Gerald Wright, and John R. McIver. 1993. Statehouse Democracy: Public Opinion and Policy in the American States. New York: Cambridge University Press.

Francis, Richard M. 1998. Predictions, Patterns, and Policymaking: A Regional Study of Devolution. Publius 28:143-160.

Gray, Virginia, and Peter Eisenger. 1997. American States and Cities, 2nd ed. New York: Longman.

Gais, Thomas L. 2000. Welfare Reform and Governance. In Learning from Leaders: Welfare Reform Policy in Five Midwestern States, ed. Carol S. Weissert. Albany, NY: The Rockefeller Institute Press.

Hamm, Keith E., and Gary F. Moncrief. 1999. Legislative Politics in the States. In Politics in the American States, 7th ed., eds. Virginia Gray, Russell L. Hanson, and Herbert Jacob. Washington, DC: CQ Press.

Hero, Rodney E. 1998. Faces of Inequality: Social Diversity in American Politics. New York: Oxford University Press.

Key, V.O., Jr. 1949. Southern Politic in State and Nation. New York: Knopf.

Liebermann, Robert C., and Greg M. Shaw. 2000. Looking Inward, Looking Outward: The Politics of State Welfare Innovation under Devolution. Political Research Quarterly 53:215-240.

Murray, Charles. 1984. Losing Ground: American Social Policy, 1950-1980. New York: Basic Books.

Peterson, Paul E. 1995. The Price of Federalism. Washington, DC: The Brookings Institution.

Peterson, Paul E., and Mark C. Rom. 1990. Welfare Magnets: A Case for a National Standard. Washington, DC: The Brookings Institution.

Rom, Mark C. 1999. Transforming State Health and Welfare Programs. In Politics in the American States, 7th ed., eds. Virginia Gray, Russell L. Hanson, and Herbert Jacob. Washington, DC: CQ Press. 
Rom, Mark C., Paul E. Peterson, and Kenneth F. Scheve, Jr. 1998. Interstate Competition and Welfare Policy. Publius 28:17-39.

Rowe, Gretchen. 2000. Assessing The New Federalism. Washington, DC: The Urban Institute.

Saffell, David C., and Harry Basehart. 1997. Governing States and Cities. New York: McGraw Hill.

Schram, Sanford F., and Joe Soss. 1998. Making Something Out of Nothing: Welfare Reform and a New Race to the Bottom. Publius 28:67-88.

Shaw, Greg M. 2000. The Role of Public Input in State Welfare Policymaking. Policy Studies Journal 28:707-720.

Skocpol, Theda. 1995. Social Policy in the United States: Future Possibilities in Historical Perspective. Princeton, NJ: Princeton University Press.

Soss, Joe, Sanford F. Schram, Thomas P. Vartian, and Erin O'Brien. 2001. Setting the Terms of Relief: Explaining State Policy Choices in the Devolution Revolution. American Journal of Political Science 45:378-394.

Walker, David B. 1995. The Rebirth of Federalism: Slouching Toward Washington. Chatham, NJ: Chatham House Publishers.

Weissert, Carol S. 2000. Learning from Midwestern Leaders. In Learning from Leaders: Welfare Reform Politics and Policy in Five Midwestern States, ed. Carol S. Weisert. Albany, NY: The Rockefeller Institute Press.

Wright, Gerald C., Robert S. Erickson, and John P. McIver. 1994. The Impact of Party Ideology. The American Review of Politics 15:305-327.

Zimmerman, Shirley L., and Constance T. Gager. 1997. A Potential Case of Social Bankruptcy: States' AFDC Payments and Their Teen Birth Rates. Policy Studies Journal 25:109-123. 